\title{
Modernidade - Mundo de sonho, Experiência do choque
}

\author{
Milena Travassos*
}

Resumo: A estética do choque (Chockerlebnis) em Walter Benjamin mantém uma interação com a modernidade, nas áreas da economia, da sociedade, estendida ao cotidiano e à arte. Este trabalho reflete sobre a forma de percepção que predomina na modernidade e na recepção cinematográfica: coletiva, super-estimulada, distraída, uma percepção do choque. Aborda o conceito de choque (Chockerlebnis) colocando-o em situação constelacional com outros conceitos como autômato (trabalho fabril), montagem cinematográfica, recepção tátil, experiência (Erfahrung) e vivência (Erlebnis). Avalia o estado de auto-alienação que a humanidade atingiu, e discute a utilização política e estética dos conceitos de faculdade mimética (Mimetisches Vermögen), sonho (Träume) e despertar (Erwachen) ante este estado.

Palavras-chave: Modernidade - Política - Estética - Choque - Cinema

\begin{abstract}
The aesthetics of shock (Chockerlebnis) in Walter Benjamin has an interaction with modernity, in the areas of economy, and society, manifested in daily aspects and art. The work discusses about which perception prevails in modernity and in movie reception: collective, super-stimulated, distracted, a sense of shock. It brings up the concept of shock (Chockerlebnis) by placing it in a constellation with other concepts such as automaton (factory work), movie editing, tactile reception, expertise (Erfahrung) and experience (Erlebnis). It analyses the state of self-alienation that humanity has reached, and discusses the political and aesthetic use of concepts such as mimetic faculty (Mimetisches Vermögen), dream (Träume) and wake (Erwachen) up before this state.
\end{abstract}

Key words: Modernity - Politics - Aesthetics - Shock - Movie

*Milena de Lima Travassos tem Mestrado em Filosofia pela UECE e é vicelíder do Grupo de Pesquisa Walter Benjamin e a Filosofia Contemporânea coordenado por Tereza Callado. 


\title{
Modernidade - Mundo de sonho, Experiência do choque
}

\begin{abstract}
"A humanidade deve despedir-se de seu passado reconciliada - e uma forma de reconciliação é a alegria".
\end{abstract}

Benjamin

O processo de industrialização capitalista marca a chegada da "modernidade", com ele a cidade ganha uma nova fisionomia. As grandes metrópoles passam por uma reestruturação urbana, a mercadoria é auratizada, o coletivo se vê imerso em um sonho (Traum), as novas técnicas de reprodução ganham visibilidade, a experiência do choque (Chockerlebnis) atinge todos os âmbitos da vida. Importante destacar a crítica de Benjamin a este processo, como também seu papel como teórico que refletiu a chegada da tecnologia e da cultura de massa, pois analisou o modo de relação entre arte e sociedade no mundo capitalista tecnológico contemporâneo. Traçaremos um percurso por entre os fenômenos que marcam a chegada da modernidade e as possibilidades abertas pela técnica cinematográfica.

A exposé de 1935, ou Paris, a capital do século XIX', abre o "livro" das Passagens ${ }^{2}$. O texto, escrito em maio de 1935, só veio a ser publicado vinte anos depois. Ao redigir essa exposé a pedido do Instituto de Pesquisa Social ${ }^{3}$, Benjamin constata em uma carta a Scholem: "meu trabalho (o das Passagens) entrou num novo estágio, aliás, o primeiro que vagamente se aproxima de um livro"4. Nesse primeiro momento, privilegiamos esse texto, tendo em vista que, por meio dele, mergulhamos na Paris do século XIX, na época de Baudelaire, no anuncio da técnica cinematográfica, na experiência do choque, figurações que caracterizam a chegada da modernidade. Alguns conceitos de Marx em $O$

\footnotetext{
${ }^{1}$ BENJAMIN, Walter. "Paris, a capital do século XIX". In: Passagens. (Trad. Irene Aron e Cleonice Paes Barreto Mourão). São Paulo: Editora UFMG, 2006.

${ }^{2}$ A composição da inacabada obra sobre as passagens de Paris, Paris, capital do século XIX, ocupou Benjamin pelo menos desde 1927 até sua morte em 1940. O que hoje conhecemos deste projeto consiste nos originais que Benjamin confiou a Georges Bataille, e que Bataille escondeu até o fim da guerra em 1945. Rolf Tiedemann, o editor alemão de Benjamin, os publicou como "Apontamentos e materiais" em 1982.

3 A pedido de Friedrich Pollock, que fundou e dirigiu na década de 1930, ao lado de Max Horkheimer, o Instituto de Pesquisa Social. Esse Instituto é conhecido hoje como Escola de Frankfurt.

${ }^{4}$ BENJAMIN, Walter; SCHOLEM, Gershom. Correspondência. (Trad. Neusa Soliz). São Paulo: Perspectiva, 1993, p. 218.
} 
Capital oferecem material relevante para a construção desse projeto $^{5}$, foram escolhidos por Benjamin para a difícil tarefa de incursão por entre os fenômenos que cercam o século XIX, um deles é o caráter fetiche da mercadoria. Afirma Benjamin: "[...] aqui o ponto central também será o desenvolvimento de um conceito clássico. Se no outro ( $O$ drama barroco alemão) tratava-se do conceito de tragédia, aqui é o caráter de fetiche da mercadoria"6.

É na moderna Paris do século XIX, que os fenômenos da economia tornam-se visíveis. Esta cidade vive um período de plena expansão do capitalismo, favorecida pelo amplo desenvolvimento das forças produtivas e pela prosperidade industrial. Tal período, Benjamin denomina de o "alto capitalismo" (Hochapitalismus), em termos qualitativos e quantitativos; nele toda a vida cotidiana encontra-se tomada pelo caráter fetiche da mercadoria, e a vida social totalmente mergulhada no sistema capitalista. Benjamin constata: "As fantasias de Grandville transferem para o universo o caráter de mercadoria"7.

Longe de pretender tecer uma crítica da ciência econômica política, Benjamin procura investigar os fatos econômicos, para entender a lógica da economia em relação à sua expressão (Ausdruck) superestrutural - a cultura da sociedade capitalista. Tal relação está no centro de seu pensamento crítico sobre o conhecimento histórico.

\begin{abstract}
A questão é, de fato a seguinte: se a infra estrutura determina de certa forma a superestrutura no material de pensamento e da experiência, mas se esta determinação não se reduz a um simples reflexo, como ela deve então ser caracterizada, independentemente da questão da causa de seu surgimento? Como sua expressão. A superestrutura é a expressão da infra-estrutura ${ }^{8}$.
\end{abstract}

\footnotetext{
${ }^{5}$ Sigmund Freud e o movimento artístico dos surrealistas também marcam a redação dessa obra. A idéia para escrever as Passagens lhe veio da leitura de O camponês de Paris (Le paysan de Paris), do surrealista Louis Aragon. Segundo Willi Bolle, a teoria interdisciplinar: filosofia, sociologia e psicologia social do Instituto de Pesquisa Social era a referencia principal de Benjamin. (BOLLE, Willi. Fisiognomia da Metrópole Moderna. São Paulo: Editora da Universidade de São Paulo, 2000, p. 51).

${ }^{6}$ BENJAMIN, Walter; SCHOLEM, Gershom. Correspondência, p. 219.

7 BENJAMIN, Walter. "Paris, a capital do século XIX". In: Passagens, p. 44.

${ }^{8}$ BENJAMIN, Walter. "Caderno K - Cidade de Sonho, Sonho de Futuro, Niilismo Antropológico, Jung". In: Passagens, p, 437 (K 2, 5).
} 
Benjamin compreende os fatos econômicos como fenômeno original, não como simples causa da cultura capitalista, haja vista que eles se mantêm nos objetos produzidos por esta cultura e Ihes dá feição, são a sua expressão. Seu interesse é investigar a especificidade dos objetos culturais do século XIX. Ao observá-los encontra a mercadoria como sua forma fundamental. Para ele, a lógica econômica da mercadoria se manifesta em uma totalidade de vivências da vida social. Benjamin estuda os fenômenos que materializam o avanço do processo capitalista, isso explica a escolha pelo século XIX, mais precisamente, pela segunda metade deste século. Paris, a "capital do luxo e da moda", é o seu objeto de pesquisa, pois melhor expressa o fundamento que Benjamin quer pensar: o conceito de caráter fetiche da mercadoria, e, em meio a esse processo, a auratização da mercadoria (Auratisierung der Waren). Neste século a forma mercadoria se expressa e ganha visibilidade imagética.

\begin{abstract}
A cidade de Paris ingressou nesse século sob a forma que the foi dada por Haussmann. Ele realizou sua transformação da imagem da cidade com os meios mais modernos que se possa pensar: pás, enxadas, alavancas e coisas semelhantes. Que grau de destruição já não provocaram esses instrumentos limitados! E como cresceram, desde então, com as grandes cidades, os meios de arrasá-las! Que imagem do porvir já não evocam! - os trabalhos de Haussmann haviam chegado ao ponto culminante; bairros inteiros eram destruídos ${ }^{9}$.
\end{abstract}

As relações sociais capitalistas são apresentadas como sonhos (Träume), se dão como experiências sociais oníricas. Benjamin pensa esses traços materiais da experiência social do século XIX como figurações oníricas de um corpo coletivo, portanto, como imagens oníricas, delirantes a serem interpretadas. Aqui, a crítica marxiana, no que diz respeito ao caráter fetiche da mercadoria, articula a dimensão onírica da experiência social destacada por Benjamin.

A preocupação de Benjamin com o caráter único e incomparável dos fenômenos leva-o a tomar As flores do mal como referência na compreensão da modernidade de seu tempo. Na modernidade, quando o significado de cada coisa passa a ser fixado pelo preço, a poesia de Baudelaire é fundamental em

\footnotetext{
${ }^{9}$ BENJAMIN, Walter. "Paris do Segundo Império - A Modernidade". In: Obras escolhidas III Charles Baudelaire um Lírico no Auge do Capitalismo. (Trad. José Carlos Martins Barbosa e Hemerson Alves Baptista). São Paulo: Brasiliense, 1989, p. 84
} 
virtude da apropriação que faz dos elementos dessa cultura para revelar a dimensão do inferno instalado em seu interior. Acompanharemos a trajetória de Baudelaire, em seu processo de reconhecimento da fantasmagoria (Phantasmagorie) própria da modernidade, mediante a crítica de Benjamin. Ela põe em primeiro plano a materialidade lingüística da obra do poeta, porque compreende que é tarefa do crítico materialista revelar a luta social que se trava no interior das linguagens. Benjamin encontra as ruas de Paris na obra de Baudelaire: multidão, flaneur, prostituta, jogador, colecionador. Com tais figurações esta cidade é apresentada alegoricamente pelo poeta:

\begin{abstract}
O engenho de Baudelaire, que se alimenta da melancolia, é um engenho alegórico. Com Baudelaire, pela primeira vez, Paris se torna objeto da poesia lírica. Não é uma poesia que canta a cidade natal, ao contrário, é o olhar que o alegórico lança sobre a cidade, o olhar do homem que se sente ali como um estranho ${ }^{10}$.
\end{abstract}

Na lírica deste poeta da modernidade, está presente uma ferrenha crítica ao progresso, ao novo, ao caráter de novidade. A visão de Benjamin dialoga com essa crítica, como também com a concepção do que Baudelaire compreende por moderno. Mesmo que Baudelaire se refira a mercadoria (nouveauté) $^{11}$ como algo que nasce novo e logo se torna velho, e Benjamin a compreenda como algo que já nasce velho, estes dois pensamentos tem profundas afinidades quando olham a Paris do século XIX.

Abrigando a efervescência revolucionária da época Paris se tornou 0 barril de pólvora da Europa. A revolução de 1848 foi diferente da de 1789 pela entrada em cena dos socialistas e dos trabalhadores da moderna indústria têxtil, sem a qual não teriam surgido os magasins de nouveautés e as galerias de Paris. Benjamin trata das galerias metropolitanas ou passagens parisienses, "mundo em miniatura", construções que têm seu surgimento marcado pelo advento do ferro e do vidro. As passagens também têm sua origem ligada ao avanço do processo econômico, visto que as mercadorias produzidas pela crescente industrialização necessitavam de um lugar para constante exposição. As passagens realizavam muito bem esse papel. Tratando das condições para

\footnotetext{
${ }^{10}$ BENJAMIN, Walter. "Paris, a capital do século XIX". In: Passagens, p. 47.

11 A nouveauté é compreendida por Benjamin como cânone das imagens dialéticas. Ver BENJAMIN, Walter. "Paris, a capital do século XIX". In: Passagens, p. 48.
} 
o surgimento das passagens, afirma Benjamin: "a maioria das passagens de Paris surge nos quinze anos após 1822. A primeira condição para seu aparecimento é a conjuntura favorável do comércio têxtil. [...] A segunda condição para o surgimento das passagens advém dos primórdios das construções de ferro" ${ }^{\prime 2}$.

O ferro, "material de construção artificial", traz consigo o novo e o antigo, pois sua utilização ainda é dominada por uma forma antiga, a da arquitetura imitando as formas arquitetônicas da Grécia antiga ${ }^{13}$. As passagens eram vistas por Benjamin como símbolo do luxo e do "progresso" de Paris, conforme o autor: "As passagens são o centro das mercadorias de luxo. Para expô-las, a arte põe-se a serviço do comerciante"14. Tais construções trazem consigo um caráter ambíguo, o de ser síntese de rua e residência. Nas passagens e em meio à multidão o flâneur, importante personagem na lírica de Baudelaire, sente-se em casa. A cidade é paisagem para ele.

O efeito narcotizante que a multidão exerce sobre o flâneur é o mesmo que a mercadoria exerce sobre a multidão. Baudelaire é preciso ao afirmar que só o mergulho na multidão permite ao poeta tornar-se moderno ${ }^{15}$. A multidão torna-se massa. A lírica de Baudelaire manifesta e decifra os fenômenos postos por ela em primeiro plano. A Paris do século XIX pode se ver representada e decifrada na escrita alegórica do poeta. Benjamin não aproximava a psicanálise e a arte reforçando a tese clássica da arte como sublimação, por isso mesmo ele pôde ver a modernidade valendo-se de Baudelaire. É no interior da multidão e nas passagens, por sua posição intermediária entre rua e residência, que o flâneur se sente em casa. O que há de específico no espaço e no tempo da modernidade é captado e descrito por Baudelaire. Sua prosa poética surge dos choques com a grande cidade.

\footnotetext{
${ }^{12}$ BENJAMIN, Walter. "Paris, a capital do século XIX". In: Passagens, pp. 39-40.

${ }^{13}$ Inicialmente os novos meios ainda não constituíram uma linguagem própria e recorrem aos artifícios já conhecidos, fora assim na arquitetura, como também no cinema. Em Pequena história da fotografia, ao falar da substituição da pintura pela fotografia Benjamin recorre a Moholy-Nagy: "As possibilidades criadoras, a serviço do novo, [diz Moholy-Nagy], são na maior parte dos casos descobertas, lentamente, através de velhas formas, velhos instrumentos e velhas esferas de atividade, que no fundo já foram liquidados com o aparecimento do novo, mas sob a pressão do novo emergente experimentam uma floração eufórica". (BENJAMIN, Pequena história da fotografia, pp. 104-05).

${ }^{14}$ BENJAMIN, Walter. "Paris, a capital do século XIX". In: Passagens, p. 40.

${ }^{15}$ BENJAMIN, Walter. "Sobre alguns temas em Baudelaire". In: Obras escolhidas III - Charles Baudelaire: um lírico no auge do capitalismo. (Trad. José Carlos Martins Barbosa e Hemerson Alves Baptista). São Paulo: Brasiliense, 1989, p. 113.
} 
Baudelaire se contrapõe aos românticos por não se identificar com a nostalgia resignada própria de muitos deles, e por reforçar a capacidade de decisão. A melancolia baudelaireana é ativa. Essas são algumas das confluências com Benjamin.

Durante toda Exposé Benjamin incorpora em sua pesquisa vários elementos que expressam as imagens oníricas do sonho coletivo presentes na cidade de Paris. Passagens, ruas, arquitetura, ferro, vidro, moda, trespassam, ou melhor, inserem-se na vida cotidiana desta cidade. Outros exemplos importantes que não escaparam ao crivo de Benjamin são a pintura e a literatura panoramáticas, anunciando antecipadamente a chegada da fotografia, como também do cinema mudo e sonoro: “...os panoramas abrem o caminho, para além da fotografia, ao cinema mudo e ao cinema sonoro"16. Os panoramas são responsáveis pela revolução proporcionada pelo encontro da arte com a técnica e expressam, segundo Benjamin, um novo sentimento de vida.

A fotografia, "nova realidade técnica e social", diferente da pintura, questionada por seu caráter subjetivo, era privilegiada por ser encontrada nela uma dimensão objetiva ${ }^{17}$. A vida nas grandes cidades sofria conseqüências do processo de industrialização capitalista, muitas pessoas estavam submetidas a um reduzido espaço de produção. Avaliando esse processo, Benjamin constata novas maneiras de viver, sentir e perceber, constata a experiência do choque como regra para o citadino. Mais recentemente, Bem Singer, em seu texto Modernidade, hiperestímulo e o início do sensacionalismo popular, investiga as mudanças na estrutura da experiência, à luz das noções evocadas por Benjamin:

[...] mas do que simplesmente apontar para o alcance das mudanças tecnológicas, demográficas e econômicas do capitalismo avançado, Simmel, Kracauer e Benjamin enfatizaram os modos pelos quais essas mudanças transformaram a estrutura da experiência. A modernidade implicou um mundo fenomenal - especificamente

\footnotetext{
${ }^{16}$ BENJAMIN, Walter. "Paris, a capital do século XIX". In: Passagens, p. 42.

${ }^{17}$ Sabemos, porém, que um lado subjetivo está sempre presente no ato de fotografar.
} 
urbano - que era marcadamente mais rápido, caótico, fragmentado e desorientador do que as fases anteriores da cultura humana ${ }^{18}$.

Vale destacar, que a escolarização compulsória, erradicando o analfabetismo, também modificou o perfil da sociedade e ampliou as possibilidades do mercado editorial. O surgimento do folhetim e sua rápida aceitação pela grande imprensa se inscrevem neste contexto. Se anteriormente era o prestigio literário do escritor que possibilitava sua publicação em folhetim, a partir do Segundo Império a individualidade do autor é minada pela voracidade dos editores e pela tendência do "público" a atribuir uma importância maior aos personagens do que àqueles que os $\mathrm{criam}^{19}$. A mercantilização e a diluição da autoria mediante a divisão do trabalho também atingiram a primeira geração de folhetistas. Benjamin remete a um panfleto de 1844 - Fabrique de romans - Maison Alexandre Dumas et $\mathrm{Cie}^{20}$ - que questionava e ironizava o ritmo frenético da produção de Dumas. Segundo os boatos da época, ele empregava clandestinamente inúmeros literatos pobres e sem nome no mercado.

Baudelaire percebeu o que se passava no mercado literário da época. Se existe um pequeno grupo de pessoas que produz alguma coisa que passa a ser disputada por muitas pessoas no mercado, o caráter dessa coisa tende a ser modificado. A incorporação do artista ao conjunto da força de trabalho não ocorreu sem profundas modificações na natureza da criação artística. É por isso que Baudelaire sempre comparou o literato e a si próprio com a prostituta. Indicio da desauratização (Eutzaubrung) do mundo e da arte.

O interesse despertado pelo tipo de romance explorado pelo folhetim, que privilegia os aspectos sentimentais, psicológicos e privados, está relacionado ao processo de acomodação, à separação empreendida pelo Estado burguês entre o homem e o cidadão, o privado e o público. As fronteiras entre esses espaços apresentam inúmeras alterações no decorrer do século XIX. No início do processo revolucionário, ainda no século XVIII, "privado" é sinônimo de conspiratório ou suspeito, a ele sobrepondo-se sempre o interesse

\footnotetext{
${ }^{18}$ SINGER, Bem. "Modernidade, hiperestímulo e o início do sensacionalismo popular". In: O cinema e a invenção da vida moderna. (Trad. Regina Thompson). São Paulo: Cosac e Faify, 2004, p. 96.

${ }^{19}$ Esse fenômeno é parecido com o que acontece hoje com o cinema hollywoodiano.

${ }^{20}$ BENJAMIN, Walter. "Paris, a capital do século XIX". In: Passagens, p. 42.
} 
"público". A redefinição burguesa do espaço privado e dos direitos individuais resultou na despolitização da vida doméstica, no fechamento do indivíduo em si mesmo e na família.

Para o homem privado, o espaço em que vive se opõe pela primeira vez ao local de trabalho. O primeiro constitui-se como "intérieur". O escritório é seu complemento. O homem privado, que no escritório presta contas à realidade, exige que o "intérieur" o sustente em suas ilusões ${ }^{21}$.

Em Experiência e pobreza, Benjamin põe em relevo a distinção entre o "homem tradicional, solene, nobre, adornado com todas as oferendas do passado", e o homem "[...] contemporâneo nu, deitado como recém nascido nas fraudas sujas de nossa época"22. Nu e solitário, visto que, após a Grande Guerra não há mais experiência em comum compartilhadas por todos. Esse novo homem ainda cultiva, entretanto, a ilusão de ao deixar rastros, protegerse, mesmo que privadamente, da desapropriação coletiva. Benjamin e Brecht, também Klee e Scheerbart, propõem um outro gesto: apaguem os rastros! Gesto que vem ressaltar a solidão, a pobreza, a desorientação, do novo homem que não mais dispõe de valores "seguros". Recomeçar a partir do zero é o que a arte propõe, não a ilusão de uma segurança privada. Jeanne Marie, em Lembrar escrever esquecer, nos fala desse gesto ilusório e da resistência coletiva proposta por Benjamin.

[...] recolher-se em sua casa, em sua família, com seus filhos, sua mulher, seu homem, seus bens, seu cachorro, seus livros etc., isto é, tentar desesperadamente ainda imprimir sua marca - deixar seus rastros - nos indivíduos próximos e nos objetos pessoais; cultivar, assim, a ilusão da posse e do controle de sua vida, quando esta escapou há tempos da determinação singular de seu dono. Tentar ainda deixar rastros seria, então, um gesto não só ingênuo e ilusório, mas também totalmente vão de resistência ao anonimato da sociedade capitalista moderna. Gesto vão porque restrito ao âmbito particular e individual, quando se trata, dizem Brecht e Benjamin, de inventar resistências coletivas ao processo coletivo de alienação, em vez de reforçá-lo por pequenas soluções privadas ${ }^{23}$.

\footnotetext{
${ }^{21}$ BENJAMIN, Walter. "Paris, a capital do século XIX". In: Passagens. p. 45.

${ }^{22}$ BENJAMIN, Walter. "Experiência e pobreza". In: Obras escolhidas $I$ - Magia e técnica, arte e política. (Trad. Sergio Paulo Rouanet). São Paulo: Brasiliense, 1994, p. 116.

${ }^{23}$ GAGNEBIN, Jeanne Marie. Lembrar escrever esquecer. São Paulo: Ed. 34, 2006, p. 115.
} 
Benjamin destacou o aparecimento do homem privado no palco da história na época de Luiz Felipe e avaliou suas conseqüências. É também no interior, sob os cuidados do colecionador, onde a arte irá procurar refúgio, afirma Benjamin: "O "intérieur" é o refugio da arte. O colecionador é o verdadeiro habitante do "intérieur". Ele se incumbe de transfigurar as coisas. Sobre ele recai a tarefa de Sísifo de despir as coisas de seu caráter de mercadoria, uma vez que as possui" ${ }^{24}$. O colecionador, habitante do interior da residência, procura resgatar as obras de arte de seu caráter de mercadoria, cria "um mundo em que as coisas estão liberadas da obrigação de serem úteis".

É no interior do lar que o burguês procura esquecer as contradições da sociedade. Os rituais domésticos, os objetos de decoração servem para manter a ilusão de um universo harmonioso. A fantasmagoria da cultura capitalista se desdobra no interior burguês: cortinas, papéis de parede, quadros, molduras rebuscadas, veludos, tapetes, estojos, devem mostrar um cenário capaz de oferecer segurança e apoio espiritual aos personagens que habitam este interior (a rua representa o perigo e o choque). Somente para o burguês a casa representa o domínio privado por excelência. Para as classes populares urbanas e rurais, ao contrário, as condições de moradia propiciavam um desenvolvimento da intimidade completamente diferente dos cultivados pela burguesia. Constrangidos a viver amontoados, os pobres eram levados a um uso privado do espaço público e a manifestações visando a redefinição de ambos.

Os modelos da vida privada no século XIX são inseparáveis das circunstâncias econômicas e sociais criadas pela indústria. Industrialização, urbanização e multidão também são fenômenos interligados. Algumas formas de afirmação da identidade nos indivíduos emergiram com o surgimento da multidão. Sob o Segundo Império, o espaço urbano parisiense começa a ser planejado e reorganizado. Nesta época Paris se torna "uma cidade estranha para os próprios parisienses".

As Exposições universais contribuem para constante transformação do espaço urbano e privado, transferem para o todo o universo o caráter de

\footnotetext{
${ }^{24}$ BENJAMIN, Walter. "Paris, a capital do século XIX". In: Passagens, p. 46.
} 
mercadoria, pois estende a autoridade da moda aos objetos de uso diário utilitário. Nelas o que vale é o valor de troca idealizado, o valor de uso passa para segundo plano. Pela primeira vez surge a palavra reclame. A publicidade procura transformar todo espectador em consumidor, mas, além de a obra de arte já se ter transformado em mercadoria, ela procura fazer que a mercadoria apareça como se fosse uma obra de arte. "A entronização da mercadoria e o brilho da distração que a cerca é o tema secreto da arte de Grandville"25. 0 reverso da auratização da mercadoria é a dessacralização da arte moderna mais consciente.

O tempo como duração perde sua importância diante do tempo mercadoria, representado de modo exemplar no slogan "tempo é dinheiro". Não é apenas a exploração inerente ao mundo do trabalho que se questiona, mas também as regras disciplinares deste mundo e sua uniformidade monótona e mecânica. Submetido à matematização do tempo moderno, o operário se divide entre o trabalho e o lazer. As Exposições Universais constituem as primeiras tentativas de administrar o tempo "livre" do trabalhador, sendo precedidas por exposições nacionais. Reportando à exposição nacional realizada no Campo de Marte, em Paris, em 1798, Benjamin escreve:

Ela nasce do desejo de "divertir as classes trabalhadoras, tornando-
se para elas uma festa de emancipação". O operariado situa-se em
primeiro plano como clientela. Ainda não se constituíra o quadro da
indústria de entretenimento. Esse quadro é formado pela festa
popularr $^{26}$.

A degradação ou perda da experiência (Erfahrung) faz parte de um longo processo que começa com as manufaturas e atinge seu apogeu na indústria moderna. O interesse de Benjamin em reunir informações sobre temas diversos, como uso do ferro na arquitetura, ferrovias, daguerreotipia, sistemas de iluminação, está vinculado a esta avaliação. A perda da experiência (Erfahrung) pelo bombardeio da informação, pela mecanização e pela divisão do trabalho industrial se traduz em automatização. A experiência é substituída pela vivência (Erlebnis). Transformado em autônomo o operário lida melhor com a máquina. Os mesmos gestos mecânicos são encontrados entre

\footnotetext{
${ }^{25}$ BENJAMIN, Walter. "Paris, a capital do século XIX". In: Passagens, p. 44.

${ }^{26}$ BENJAMIN, Walter. "Paris, a capital do século XIX". In: Passagens, p. 44.
} 
os transeuntes das ruas e as multidões que circulam nas grandes cidades. A super estimulação dos sentidos se converte em torpor, em anestesiamento do olhar, do corpo, da memória, dos sentidos.

A exaustiva tarefa de fazer a análise materialista, crítica, política e estética do "alto capitalismo" (Hochapitalismus) expresso na forma mercadoria que impregna os fenômenos na vida social, a que Benjamin se propôs, requer distanciamento. Após emergir do sonho que foi o século XIX, ou melhor, no limiar, entre o sonho e o despertar (Erwachen), os objetos históricos se tornam cognoscíveis, compreensíveis, legíveis. O limiar como momento de perigo, como momento da cognoscibilidade (Jetzt der Erlcennbarkeit). Nos anos 30 do século XX, marcado pelo abalo da economia mercantil, pelo estremecimento econômico; o capitalismo, aos olhos de Benjamin, estava em crise, e, por isso, pode ser melhor compreendido. "Com o abalo da economia de mercado, começamos a reconhecer os monumentos da burguesia como ruínas antes mesmo de seu desmoronamento" 27 .

As passagens, a moda, a propaganda, as exposições universais, são traços materiais da experiência vivida pelo homem moderno na Paris do século XIX, são as imagens oníricas do sonho coletivo. Estes traços são penetrados e decifrados pelo olhar detalhista de Benjamin, olhar que vê nos fragmentos esquecidos por aqueles que contam a história, a possibilidade de, ao usá-los, formular numa grande montagem, uma outra história, a história dos vencidos ou dos oprimidos (esquecidos). É esse o trabalho da dialética na imobilidade, olhar o reverso do status quo. O fragmento é visto por Benjamin como miniatura do mundo e representação do espírito de uma época.

Adotando um procedimento idêntico ao catar resíduos no lixo da história oficial $^{28}$, Benjamin construiu uma imagem da Europa do século XIX valendo-se dos seus rastros. Este modo de narrar é oposto ao que pretende contá-la "como ela realmente foi", isso é, ao que cultiva as ilusões de neutralidade do historiador, mas que termina por acentuar uma empatia para com um

\footnotetext{
${ }^{27}$ BENJAMIN, Walter. "Paris, a capital do século XIX". In: Passagens, p.51.

${ }^{28}$ Procedimento semelhante ao método da montagem no cinema, da colagem nos surrealistas e dadaístas, como de outras práticas artísticas. Procedimento presente também no trapeiro, figura heróica da poesia de Baudelaire que Benjamin realçou.
} 
determinado período. A tarefa de Benjamin é a de um historiador crítico materialista, que faz a transição da imagem onírica à imagem dialética.

Benjamin apresenta a modernidade como mundo de sonho, no qual o despertar (Erwachen) coletivo deve se dá como sinônimo de uma conscientização revolucionária de classe. Benjamin insistia no fenômeno coletivo e histórico do sonho. Mas esse sonho coletivo é inconsciente, ele passa totalmente despercebido para a massa sonhadora. Os que nele se encontram permanecem distraídos. Enquanto massa desagregada, autômata e irrefletida, conserva-se em um estado inconsciente de si mesma. No mundo onírico mercadológico, cada consumidor participa desse sonho, ao se deixar tomar por esse mundo, passando a crer nele como exclusivamente pessoal, mesmo a despeito de todas as evidências concretas do contrário. A coletividade criada na lógica econômica só se dá de forma alienante, cada indivíduo é parte anônima da massa. Vejamos:

\begin{abstract}
O século XIX, um espaço de tempo [Zeitraum] (um sonho de tempo [Zeit-traum]), no qual a consciência individual se mantém cada vez mais na reflexão, enquanto a consciência coletiva mergulha em um sonho cada vez mais profundo. Ora, assim como aquele que dorme e que nisso se assemelha ao louco - dá início a viagem macrocósmica através de seu corpo, e assim como os ruídos e sensações de suas próprias entranhas, [...], que no homem sadio e desperto se confundem no murmúrio geral do corpo saudável produzem, graças à inaudita acuidade de sua sensibilidade interna, imagens delirantes ou oníricas que traduzem e explicam tais sensações, assim também ocorre com o coletivo que sonha e que, nas passagens, mergulha em seu próprio interior. É a ele que devemos seguir, para interpretar o século XIX, na moda e no reclame, na arquitetura e na política, como a conseqüência de suas visões oníricas ${ }^{29}$.
\end{abstract}

É a ideologia da classe dominante que o sonho coletivo manifesta, e dessa forma as relações entre as coisas espelham as relações sociais de exploração. "Nas passagens, o mundo da produção desaparecia e ficava só o espaço da circulação, do consumo, da compra e venda. O sonho da burguesia se corporificava: o luxo do paraíso encobria o inferno da exploração"30. Implicado nesse estado, o ideal burguês da democracia passa por uma

\footnotetext{
${ }^{29}$ BENJAMIN, Walter. "Caderno K - Cidade de sonho e morada de sonho, sonhos de futuro, niilismo antropológico, jung". In: Passagens, p. 434

${ }^{30}$ KONDER, Leandro. Walter Benjamin - o Marxismo da Melancolia. Rio de Janeiro: Campus, 1989, p. 90.
} 
limitação, a liberdade, nesse contexto, passa a ter um sentido reducionista, tornara-se equivalente a capacidade de consumir. Benjamin escreve que no século XIX a "igualdade" (egalité) gerou sua própria fantasmagoria (Phantasmagorie) e que "revolução" (revolution) veio a ter o mesmo significado de "liquidação total"."11

O século XIX gera uma nova fisionomia para a cidade, para o trabalho, para o coletivo, para o corpo e sua sensibilidade; por conseguinte também para a arte. Se os Panoramas, como vislumbrado por Benjamin, anunciaram uma nova forma de arte, essa arte se distanciava dos moldes conceituais, como do fazer artístico, cultivados pela história da arte tradicional. Sua história e conceitos ainda estavam por ser construídos ao longo do século XX. Benjamin avalia o potencial revolucionário inerente às novas técnicas de arte, e celebra a chegada da fotografia e do cinema, sendo assim, volta a sua atenção para elas. A estética do choque presente nos vários âmbitos da vida urbana, no trabalho, no contato com a multidão e com o trafego, se estende è experiência com a arte.

Baudelaire inscreveu o declínio da aura e a vivencia do choque no âmago de sua poesia, transformando essas experiências esvaziadas em matéria de arte, em uma experiência poética das mais expressivas. Mas a estética do choque teve que esperar até a técnica cinematográfica para atingir a sua maturidade. No ensaio Sobre alguns temas em Baudelaire Benjamin afirma: "No filme, a percepção sob a forma de choque (Schockformiges) se impõe como princípio formal. Aquilo que determina o ritmo da produção na esteira rolante está subjacente ao ritmo da receptividade, no filme"32. A obra de arte tradicional (clássica) é marcada por uma relação de recolhimento individualizado que suga a quem a observa, ela se dispõe à contemplação do observador pelo tempo que ele deseje. Já no cinema, as imagens impõem uma visibilidade "autoritária" e fragmentada, mas são elas que mergulham no fluxo disperso do espectador. Ante a sucessão de imagens do filme, o espectador

\footnotetext{
${ }^{31}$ Ver a Exposé de 1935. (Em uma analogia com essa constatação, reporto-me a um comercial da lanchonete Habib's, veiculado na TV, este me chamou a atenção pelo absurdo de sua proposta: vinculava a super promoção com um fato revolucionário, usando a imagem de um comunista revolucionário cubano (imitando o Fidel Castro) para anunciar a redução no preço das esfihas).

${ }_{32}$ BENJAMIN, Walter. "Sobre alguns temas em Baudelaire". In: Obras escolhidas III - Charles Baudelaire: um lírico no auge do capitalismo, p. 125.
} 
precisa estar totalmente presente e disponível, de outra forma, os choques das imagens não poderiam ser absorvidos. É essa condição de percepção da arte que o cinema instaura. De acordo com Benjamin:

A associação de idéias do espectador é interrompida imediatamente, com a mudança da imagem. Nisso se baseia o efeito de choque provocado pelo cinema, que, como qualquer outro choque, precisa ser interceptado por uma atenção aguda ${ }^{33}$.

Surge uma fruição totalmente diferente da experiência tradicional aurática ante uma obra de arte. Antes do cinema os artistas dadaístas já se colocavam em combate contra a percepção aurática que tem sua expressão modelar na forma de contemplação estática de um quadro renascentista ${ }^{34}$. "De espetáculo atraente para o olhar e sedutor para o ouvido, a obra convertia-se em um tiro" 35 . Assim se apresentavam as "obras" dadaístas, situadas a um passo do cinema, por nos atingir em uma ordem tátil. Benjamin introduz o argumento do choque físico sobre o espectador, próprio do movimento dos quadros na tela de projeção. A recepção cinematográfica será então caracterizada como sendo de ordem tátil, isto é, baseia-se na mudança de lugares e ângulos, que golpeiam intermitentemente o espectador. As tensões que marcavam o fim do século XIX e o início do século XX eram postas em cena através do estímulo tátil, este passou a fazer parte até mesmo do ato de olhar. O corpo e o olho tornam-se receptáculos dos choques estéticos, 0 cinema demonstra bem isso, nele, as sensações - o estético - criam relevo:

Mas nada revela mais claramente as violentas tensões do nosso
tempo que o fato de que essa dominante tátil prevalece no próprio
universo da ótica. É justamente o que acontece no cinema, através
do efeito de choque de suas seqüências de imagens. O cinema se
revela assim, também desse ponto de vista, o objeto atualmente mais

${ }^{33}$ BENJAMIN, Walter. "A obra de arte na arte na era de sua reprodutibilidade técnica". In: Magia e técnica, arte e política, p. 192.

${ }_{34}$ Diante da obra de arte tradicional o espectador contempla uma apresentação plástica e muitas vezes figurativa de um espaço, um volume tridimensional recortado em largura e altura pela moldura do quadro, e que apresenta um conteúdo figurativo submetido ao rigoroso sistema da perspectiva geométrica. Os dadaístas, com as suas colagens, romperam com esse tipo de fruição, conteúdo e de formato.

${ }^{35}$ BENJAMIN, Walter. "A obra de arte na arte na era de sua reprodutibilidade técnica". In: Magia e técnica, arte e política, p. 191. 
importante daquela ciência da percepção que os gregos chamavam de estética ${ }^{36}$.

O cinema ofereceu à nova sensibilidade, saturada de "violentas tensões" em seu cotidiano, uma nova forma de arte, cuja essência é a sucessão brusca e rápida de imagens, que se impõem ao espectador como uma seqüência de choques. A forma cinema que surgia permitiu que as desvantagens potenciais da modernidade se tornassem vantagens estéticas: fragmentação, velocidade, deslocamento e choque tornam-se montagem. Foi essa forma da experiência em movimento que ligou o cinema à experiência da vida diária na modernidade. Essa estrutura refletia a era moderna, também fragmentada e descontínua. Leo Charney, no ensaio Num instante: o cinema e a filosofia, discute essa questão:

\begin{abstract}
Para Benjamin, a irrupção da modernidade surgiu nesse afastamento da experiência concebida como uma acumulação contínua em direção a uma experiência dos choques momentâneos que bombardearam e fragmentaram a experiência subjetiva como granadas de mão. [...] Experimentar os choques era experimentar 0 instante. [...] $O$ choque empurrava o sujeito moderno para 0 reconhecimento tangível da presença do presente. Na presença imediata do instante, o que podemos fazer - a única coisa que podemos fazer - é senti-lo ${ }^{37}$.
\end{abstract}

Benjamin propõe sentir o choque, e, na medida do possível, não se deixar anestesiar por sua constante aparição. Sair do estado de alienação e dormência, voltar a sentir, é essa uma das funções principais da estética a que Benjamin se reporta ao tratar do cinema. Em correspondência com Charney, e diante desse estado esvaziado de sentido, Susan Buck-Morss compreende que no entendimento de Benjamin a arte pode despertar os sentidos, pois: "[...] já não se trata de educar o ouvido não refinado para que escute música, senão de devolver-Ihe a capacidade de ouvir. Já não se trata de treinar o olho para a contemplação da beleza, senão de restaurar a perceptibilidade ${ }^{38 .}$

\footnotetext{
${ }^{36}$ BENJAMIN, Walter. "A obra de arte na arte na era de sua reprodutibilidade técnica". In: Magia e técnica, arte e política, p. 194.

${ }^{37}$ CHARNEY, Leo. "Num instante: o cinema e a filosofia". In: O cinema e a invenção da vida moderna. (Trad. Regina Thompson. São Paulo: Cosac e Faify, 2004, pp. 323-324.

${ }^{38}$ BUCK-MORSS, Susan. "Estética y anestésica: una reconsideración del ensayo sobre la obra de arte". In: Walter Benjamin, escritor revolucionario, (Trad. espanhola de Mariano López Seoane). Buenos Aires: Ed. Interizona, 2005, p. 190.
} 
Os golpes a que está sujeito o homem moderno não são apenas os da sucessão das imagens sobre uma tela de projeção numa sala de exibição cinematográfica. Aqueles que circulam nas grandes metrópoles não têm como se esquivar de tais golpes. E o cinema, de fato, é a forma de arte

[...] correspondente aos perigos existenciais mais intensos com os quais se confronta o homem contemporâneo. Ele corresponde a metamorfose profundas do aparelho perceptivo, como as que experimenta o passante, numa escala individual, quando enfrenta 0 tráfico, e como as experimenta, numa escala histórica, todo aquele que combate a ordem social vigente ${ }^{39}$.

A indústria fabril e bélica produzem no homem, pelo contato diário com os aparatos técnicos, uma consciência alienada, automatizada e anestesiada. Todo o corpo se encontra adormecido. Com a indústria cinematográfica, com o filme, nasce a possibilidade de penetrar nesse escudo adormecido e não somente adestrar esse corpo para melhor receber os choques e fortalecer as suas defesas. Benjamin afirma que "uma das funções sociais mais importantes do cinema é criar um equilíbrio entre o homem e o aparelho" 40 .

As imagens urbanas justapostas precisam ser vistas para levar ao despertar revolucionário. O cinema exercia uma função política ao permitir a recriação mimética do ritmo da cidade, que não seria somente uma forma de submissão, mas de reapropriação. Benjamin não discutirá no ensaio $A$ obra de arte na era de sua reprodutibilidade técnica acerca da especificidade da linguagem cinematográfica e tampouco se atém à distinção entre cinema de arte e cinema de entretenimento. O que lhe interessa são as implicações sociais, éticas e políticas desta linguagem na vida moderna. O cinema como forma de expressão e como forma de provocação, é um mecanismo que permite a reprodução tecnológica de sonhos coletivos ${ }^{41}$, abrindo espaço para um reconhecimento crítico de tal situação.

\footnotetext{
${ }^{39}$ BENJAMIN, Walter. "A obra de arte na era de sua reprodutibilidade técnica". In: Obras escolhidas I - Magia e técnica, arte e política, p. 192.

40 BENJAMIN, Walter. "A obra de arte na era de sua reprodutibilidade técnica". In: Obras escolhidas I - Magia e técnica, Arte e Política, p. 189.

${ }^{41}$ BENJAMIN, Walter. "A obra de arte na era de sua reprodutibilidade técnica". In: Obras escolhidas I - Magia e técnica, Arte e Política, p. 190.
} 
A crise da percepção fora delineada em virtude dos constantes choques aos sentidos próprios do cotidiano da vida moderna. A linha de montagem da produção, o contato com a multidão e a guerra denotam bem isso. Imerso em um território super estimulante de imagens desconexas, o olhar encontra-se constantemente distraído, ao passo que a consciência é incumbida de amortecer os choques, em uma relação que registra as impressões sem as experimentar - uma relação de vivencia. O choque é "amortecido e aparado pelo consciente" ${ }^{\prime 42}$, para evitar um efeito traumático. Benjamin valoriza 0 contato com as novas técnicas miméticas como forma de preparar criticamente o homem (a massa) para a convivência com esses novos estímulos. "Diante dessa segunda natureza, que o homem inventou e a muito não controla, somos obrigados a aprender, como outrora diante da primeira. Mais uma vez, a arte põe-se a serviço desse aprendizado ${ }^{43}$ ". O cinema é dotado de um potencial capaz de proporcionar aos espectadores um conhecimento da existência moderna de forma reflexiva.

O conceito de mimese é de fundamental importância para a teoria estética de Benjamin. O homem é naturalmente dotado com a capacidade de gerar semelhança, "na verdade, talvez não haja nenhuma de suas funções superiores que não seja decisivamente co-determinada pela faculdade mimética"44. Na infância, como forma de exercer domínio sobre as suas experiências, as crianças se assemelham instintivamente aos objetos em que entram em relação. "Os jogos infantis são impregnados de comportamentos miméticos, que não se limitam de modo algum à imitação de pessoas" ${ }^{\prime 4}$. Benjamin encontra no cinema a possibilidade exemplar de uma tecnologia mimética crítica e política. Essa nova técnica possui potencial para educar os seus espectadores efetivamente para a utilização da faculdade mimética. $O$ filme pode atuar como um meio capaz de reconstruir a capacidade de colecionar experiência desarticulada do cotidiano pelo processo da

\footnotetext{
${ }^{42}$ BENJAMIN, Walter. "Sobre alguns temas em Baudelaire". In: Obras escolhidas - Charles Baudelaire um Lírico no Auge do Capitalismo, p. 111.

${ }^{43}$ BENJAMIN, Walter. "A obra de arte na era de sua reprodutibilidade técnica". In: Obras escolhidas I-Magia e técnica, Arte e Política, p. 174.

${ }^{44}$ BENJAMIN, Walter. "A doutrina da semelhança". In: Obras escolhidas I - Magia e técnica, Arte e Política, p. 108.

${ }^{45}$ BENJAMIN, Walter. "A doutrina da semelhança". In: Obras escolhidas I - Magia e técnica, Arte e Política, p. 108.
} 
industrialização, e não apenas como defesa contra o trauma provocado por esse processo. "Com a representação do homem pelo aparelho, a autoalienação humana encontrou uma aplicação altamente criadora"46.

Benjamin tece elogios ao cinema russo por estreitar a distância entre o autor e o público, por representar o homem e o mundo, e aos filmes de Charles Chaplin, pois ao assemelharem-se com a fragmentação que ameaça a experiência, terminam por resgatar essa capacidade. A sociedade precisa "fazer da técnica o seu órgão", recriar mimeticamente, ou traduzir na linguagem humana o potencial expressivo da nova realidade tecnológica e retomar 0 controle desse aparato técnico em uma relação não submissa. Tal atitude pode reestabelecer a conexão entre a imaginação e o tecido de inervação física, que foi rompido em virtude da cultura burguesa e por sua educação e socialização castradoras. O reestabelecimento dessa conexão é justamente o aspecto político da questão.

O filme serve para exercitar o homem nas novas percepções e reações exigidas por um aparelho técnico cujo papel cresce cada vez mais em sua vida cotidiana. Fazer do gigantesco aparelho técnico do nosso tempo o objeto das inervações humanas - é essa a tarefa histórica cuja realização dá ao cinema o seu verdadeiro sentido ${ }^{47}$.

Se para a criança ${ }^{48}$ os brinquedos (Spielzeugen), expressões das transformações da sensibilidade e da produção material modernas, são instrumentos superados pela brincadeira quando as crianças reconhecem nelas e com elas reelaboram o mundo e o seu corpo, em um hábito repetido para a formação do homem adulto, o filme pode ser um exemplo desse reconhecimento e reelaboração. As brincadeiras são, então, como que companhias solidárias comparadas ao material sobre o qual se debruçam os artistas (poesia, filme, fotografias, pinturas, música), ao com ele compartilharem semelhante potencial de natureza estética. As brincadeiras infantis e as obras de arte dominam o material livremente, mas com método,

\footnotetext{
${ }^{46}$ BENJAMIN, Walter. "A obra de arte na era de sua reprodutibilidade técnica". In: Obras escolhidas I - Magia e técnica, Arte e Política, p. 180.

${ }^{47}$ BENJAMIN, Walter. "A obra de arte na era de sua reprodutibilidade técnica". In: Obras escolhidas I - Magia e técnica, Arte e Política, p. 174.

${ }^{48}$ Walter Benjamin foi um autor muito interessado na infância, tomando-a mesmo como um dos índices de construção de sua teoria da modernidade.
} 
ainda que nem sempre os artistas, de ambos os tipos, saibam exatamente 0 destino de cada processo.

A cognição das crianças é tátil, vinculada à ação e com potencial revolucionário. Também por essas características Benjamin aproxima os artistas (como produtores) das crianças. Eles lutam por conservar a capacidade ativa do gesto transformador e a forma com que esse gesto se dá ${ }^{49}$. Em tempos de crise da percepção, Benjamin aposta no poder inerente às respostas ativas e propositivas enviadas ao mundo antecipadamente ${ }^{50}$, muitas vezes, através do campo artístico em direção às massas. "E, como os indivíduos se sentem tentados a esquivar-se a tais [novas] tarefas [dadas à percepção], a arte conseguirá resolver as mais difíceis e importantes sempre que possa mobilizar as massas" ${ }^{\prime 2}$.

Enquanto objeto estético de recepção coletiva, o cinema deve arrancar a massa da alienação, do anestesiamento em que se encontra. Novamente segundo Buck-Morss, Benjamin espera que a arte, no cinema, possa "desfazer a alienação do aparato sensorial do corpo, restaurar o poder instintual dos sentidos corporais humanos em nome da auto-preservação da humanidade, e isto, não através do rechaço às novas tecnologias, mas pela passagem por elas"52. Como ressaltado por Jeanne Marie, Benjamin propõe a invenção de resistências coletivas ao processo coletivo de alienação, em vez de reforçá-lo por pequenas soluções privadas, diríamos também, capitalistas. O cinema pode ser uma dessas resistências coletivas, mas, "não se deve, evidentemente, esquecer que a utilização política desse controle terá que esperar até que o cinema se liberte da sua exploração pelo capitalismo"53. A técnica cinematográfica deve se desvencilhar da ideologia da classe dominante, pois ao permanecer dominado às condições materiais capitalistas,

\footnotetext{
${ }^{49}$ Artistas e escritores produtores capazes de pensarem e agirem de um modo realmente revolucionário seu próprio trabalho, sua relação com os meios de produção e sua técnica.

50 "Pois os grandes escritores, sem exceção, fazem suas combinações em um mundo que vem depois deles, como as ruas parisienses dos poemas de Baudelaire só existiram depois de 1900 e também não antes disso os seres humanos de Dostoievski". (Walter Benjamin, "Casa mobiliada. Principesca. Dez cômodos". In: Rua de mão única. (Trad. Rubens Rodrigues Torres Filho). São Paulo: Brasiliense, 1995, p. 15.)

${ }^{51}$ BENJAMIN, Walter. "A obra de arte na era de sua reprodutibilidade técnica". In: Obras escolhidas I - Magia e técnica, Arte e Política, p. 194.

${ }^{52}$ BUCK-MORSS, Susan. "Estética e Anestética: O "Ensaio sobre a obra de arte" de Benjamin reconsiderado". In: Travessia 33 - revista de literatura, p. 12.

${ }^{53}$ BENJAMIN, Walter. "A obra de arte na era de sua reprodutibilidade técnica". In: Obras escolhidas I - Magia e técnica, Arte e Política, p. 180.
} 
ele se sujeita à pressão do mercado e a ser meramente mercadoria, constituise em ilusão coletiva e concreta, ou seja, será uma fantasmagoria, que não cumprirá nenhuma tarefa política emancipatória.

\section{REFERÊNCIAS}

BENJAMIN, Walter. Obras escolhidas I - Magia e técnica, Arte e Política. Trad. Sergio Paulo Rouanet. São Paulo: Brasiliense, 1994.

- Obras escolhidas II - Rua de mão única. Trad. Rubens Rodrigues Torres Filho. São Paulo: Brasiliense, 1995.

. Obras escolhidas III - Charles Baudelaire um Lírico no Auge do Capitalismo. Trad. José Carlos Martins Barbosa e Hemerson Alves Baptista. São Paulo: Brasiliense, 1989.

. Passagens. Trad. Irene Aron e Cleonice Paes Barreto Mourão.

São Paulo: Editora UFMG, 2006.

. Reflexões sobre a criança, o brinquedo e a educação. Trad.

Marcus Vinicius Mazzari. São Paulo: Editora 34, 2007.

BENJAMIN, Walter; SCHOLEM, Gershom. Correspondência. Trad. Neusa Soliz. São Paulo: Perspectiva, 1993.

BOLLE. Willi. Fisiognomia da Metrópole Moderna. $2^{2}$ ed. - São Paulo: Editora da Universidade de São Paulo, 2000.

BUCK-MORSS, Susan. Walter Benjamin, escritor revolucionario. Trad. espanhola de Mariano López Seoane. Buenos Aires: Ed. Interizona, 2005.

. "Estética e Anestética: O "Ensaio sobre a obra de arte" de Benjamin reconsiderado". In: Travessia 33 - revista de literatura. Trad. Rafael Lopez Azize. Santa Catarina: Editora da UFSC, 1980.

.Dialética do olhar - Walter Benjamín e o projeto das passagens.

Trad. Ana Luiza Andrade. Belo Horizonte: Editora UFMG, 2002.

CALLADO, Tereza de Castro. O drama da alegoria no século XVII barroco in: Kalagatos, volume 2, Fortaleza, Eduece, 2004. 
CHARNEY, Leo; SCHWARTZ, Vanessa R. (org). O cinema e a invenção da vida moderna. Trad. Regina Thompson. São Paulo: Cosac e Faify, 2004.

GAGNEBIN, Jeanne Marie. Lembrar escrever esquecer. São Paulo: Ed. 34, 2006.

KONDER, Leandro. Walter Benjamin - o Marxismo da Melancolia. $2^{\underline{a}}$ ed. - Rio de Janeiro: Campus, 1989. 